\title{
Democratization and Ethnic Politics in Indonesia: Nine Theses
}

\author{
Edward Aspinall
}

\begin{abstract}
After the downfall of President Suharto in 1998, communal violence occurred in several Indonesian provinces, producing an image of the country as one characterized by strong ethnic politics. In this article, I propose that this image is mistaken. The political salience of ethnicity has subsided greatly as a new democratic system has settled into place. Overall, Indonesia is a weakly ethnicized polity. Ethnicity still counts in arenas such as local elections, but what prevails is a soft form of ethnic politics, with few of the deep disputes about ethnohistory or cultural policy that occur in more ethnicized polities. Moreover, rather than producing ethnic polarization, democratization has created powerful new norms of compromise. I present this overarching argument by advancing nine general theses on Indonesian ethnic politics and by pointing to explanations concerning institutional crafting, historical legacies, and the deep architecture of politics, notably the prevalence of patronage. Rather than positing definitive answers, I propose new questions and frameworks for investigating the weakness of ethnic politics in contemporary Indonesia. KEYwORDS: democratization, ethnicity, Indonesia, ethnic conflict, nationalism, elections, democratic institutions
\end{abstract}

DEMOCRATIZATION PRODUCED AN IMAGE OF INDONESIA AS A COUNTRY AFflicted by contentious and sometimes violent ethnic politics. After President Suharto resigned in 1998, Indonesia went from being a highly centralized polity that repressed ethnonationalist mobilization to one that was both decentralized and affected by severe communal and separatist violence in several provinces. Even in parts of the country where violence did not occur, there were various forms of ethnic political mobilization-for example, movements aiming to create new provinces or districts or demanding that preference be given to locals over migrants in government employment. However, it now increasingly appears that this new prominence of ethnic politics was a transitional phenomenon. With a new democratic system settling into place, ethnicity is losing political salience. In most of Indonesia, ethnic affiliation matters surprisingly little 
in everyday politics, and ethnic symbols are either rarely mobilized in the political domain or are mobilized only in a perfunctory and superficial manner. We see relatively few of the deep disputes about ethnohistory, language, or cultural policy that feature prominently in more ethnicized polities. Ethnic violence has declined steeply, and ethnic coalition building and cooperation, rather than conflict, are the norm at the local level.

To flesh out this general picture, I advance in this article nine theses about ethnic politics in contemporary Indonesia. The first three of these theses are descriptive claims that go to establishing the general case that ethnic politics in Indonesia today are relatively weak. Theses four and five elaborate on the nature of ethnic politics at the local level in ways that further illustrate their frail and nonconflictual character. Theses six, seven, and eight point toward causal arguments. Thesis nine notes important exceptions to the general picture presented so far, pointing out that in a few key provinces a hardened form of ethnic politics still prevails and is likely to do so for the foreseeable future.

While my primary aim is to sketch some general characterizations of the nature of ethnic politics in contemporary Indonesia, I also begin the task of exploring causation. How is it that Indonesia has defied so many predictions early in its transition and become a country where ethnicity seems to have such limited impact on political life? I note the influence of historical legacies and the inclusivist traditions of Indonesian nationalism, but I emphasize two other factors. The first, and most relevant for comparative studies of ethnic politics, is institutional design. Democratization itself was important, because democratic elections, especially the initiation of direct elections for local government heads and deputy heads, increased the incentives for political actors in plural regions to cooperate across ethnic lines in their pursuit of political power and resources. But it was not merely the fact of democratization that counted but the particular shape that it took. A suite of institutional reforms implemented relatively early in Indonesia's democratic transition conspired to undercut the role that ethnicity would play in national political life and to tame the ethnic passions that had been so powerfully unleashed. In particular, rules governing political parties and elections effectively excluded local parties from electoral contestation, preventing ethnicity from finding a foothold in the party system. Devolution of political and fiscal authority to the hundreds of district governments, rather than the few dozen provinces, and the subsequent proliferation of administrative regions, shifted the locus of political contestation to the lower levels of the political system. This context advantaged smaller rather than larger identity categories in political contests, contributing to a fragmentation of Indonesia's ethnic map and broadening the possibilities for ethnic coalition building. 
The second factor that helped tame ethnic politics concerns the deep structures underpinning Indonesian politics-namely, the ubiquity of patronage distribution as a means of binding together not only elites and their followers but also otherwise competing political groups. The dominance of predatory elites in Indonesia's new democracy has been excoriated by many observers and rightly identified as a source of the deeply rooted corruption that continues to bedevil Indonesia's democratic consolidation. However, these elites' dominance has also been accompanied by a culture of deal making and compromise that in the arena of ethnic politics, as well as in some other areas of political life, has had important conflict-ameliorating effects. In Indonesia, patronage networks on the whole tend to cross ethnic lines rather than harden them, and to blunt ethnic competition rather than intensify it.

Before I proceed to detail the theses, some definitions and general background material, as well as a caveat, are in order. As far as definitions go, the primary task is to define ethnic politics. The preliminary step is to clarify what we mean by ethnicity. Definitions range from rather comprehensive enumerations of characteristics, such as that of Anthony Smith (1986, 22-30), who requires "a collective name," "a common myth of descent," "a shared history," "a distinctive shared culture," "an association with a specific territory," and "a sense of solidarity," to simpler forms, such as one offered by Kanchan Chandra (2006, 399), who defines ethnic identity as "a subset of identity categories in which eligibility for membership is determined by attributes associated with, or believed to be associated with, descent." As understood here, the place of religion is ambiguous: in many cases, religion is part of the "distinctive shared culture" that defines an ethnic group, but elsewhere it acts as a category that cuts across and transcends ethnic particularity. ${ }^{1}$ It is also important, as Rogers Brubaker $(2002,167)$ puts it, to emphasize that ethnicities "should be conceptualized not as substances or things or entities or organisms or collective individuals . . but rather in relational, processual, dynamic, eventful and disaggregated terms." In particular, ethnicity is above all relational; it concerns recognition of difference and the processes by which "people-whose boundaries may be loosely or tightly defined-distinguish themselves from other people" (Fenton 1999, 6). Culture, descent, and so on are merely the dead ingredients of ethnicity: "For ethnicity to spring to life it is necessary that real or perceived differences of ancestry, culture and language are mobilised in social transactions" (Fenton 1999, 6). Ethnic politics then involve not just referencing such "dead ingredients" in the public sphere, but doing so in a way that highlights differences between groups.

If we view politics rather narrowly as focusing on state authority, it follows that ethnic politics is the mobilization or utilization of ethnic 
categories based on recognition of difference in order to capture state power, influence state policy, or structure state institutions. This definition allows for both intense and weak influence of ethnicity in at least two fields: the field of political mobilization and that of state structures and policies. Thus, as regards political mobilization, we may find instances of "hard" ethnic political mobilization, in which a large proportion of activity in civil and political society is conducted by ethnic political movements, which, according to Milton Esman (1994, 27), are groups that seek "to combat ethnic antagonists or to impress ethnically defined interests on the agenda of the state." But much softer forms of ethnic political mobilization are also possible, as when contestants for political office mobilize ethnic symbols in order to garner support but do not claim to be pursuing dominance or primacy for their own group at the expense of others. Similarly, regarding the policies and structures of the state, it is possible to range from a highly ethnicized polity, where the state allocates resources and determines policy with explicit reference to ethnic categories, to a weakly ethnicized polity that is blind, at least formally, to ethnic distinctions.

Some brief words are in order about the ethnic composition of Indonesia. The Indonesian population census of 2000 was the first to ask questions about ethnicity since a census conducted in 1930 during Dutch colonial rule. The Indonesian Bureau of Statistics categorized the population according to 1,072 separate ethnic codes (in itself a problematic process, but one that we will set aside for present purposes). As expected, the census revealed that by far the largest single group is the Javanese, with 84 million people representing about 42 percent of Indonesia's then total population of 200 million. The second largest group, the Sundanese (15 percent, 31 million people), are native to West Java, where they make up 74 percent of the population. Though there are significant ethnic minorities in Java, overall the population is relatively homogenous through much of the island (thus, in the heavily populated province of Central Java, 98 percent are Javanese and the figure for East Java is 79 percent). Such demographic dominance makes ethnicity less contentious politically in much of Java (although, of course, in Java too there still can be ethnic conflict at the microlevel-for example, over the economic and political role of ethnic Chinese). Accordingly, relatively few of the observations I put forward here are based on examples from that island.

Outside Java, the ethnic map is generally much more complex. Great swaths of the country are multiethnic, with no single ethnic group being in a majority in twenty-one of thirty-three provinces (all but two-Jakarta 
and Banten-of these twenty-one are located outside Java). The pattern of variation is considerable, from provinces like West Sumatra, Bali, and Gorontalo, where the largest group numbers more than 80 percent of the provincial population, to those like West Kalimantan or Papua, where there is extreme ethnic fractionalization and the largest groups are only a little more than 10 percent. In many of these so-called Outer Island provinces, there are also significant migrant populations: Javanese are the first or second largest group in three of Kalimantan's four provinces and form over 20 percent of the population in six of Sumatra's nine provinces. ${ }^{2}$

Of course, the mere fact that a set number of ethnic groups is enumerated by statisticians, and that individuals identify themselves according to these categories when asked by census takers, belies the messy complexity of ethnicity on the ground. Many individuals are themselves products of mixed marriage and thus might think of themselves as crossing ethnic categories (according to the census, ethnicity is patrilineal and persons are identified by the ethnic category of their father). At the same time, even many individuals of less complicated parentage have more than one potential ethnicity with which they can identify. Thus, to cite just two obvious examples, in North Sumatra and in Kalimantan, many individuals can identify themselves by the overarching ethnonyms Batak and Dayak, respectively, yet also identify with smaller ethnic and/or regional identities. Cross-cutting cleavages based on religion and place of origin can also be very significant politically.

These observations point to a caveat: the very diversity and complexity of Indonesia's ethnic map make generalization difficult. Some regions are very ethnically diverse, others much less so; some regions have seen intense ethnic mobilization, including violence, while most have been quiescent. Consequently, the generalizations that follow are tentative and intended more as starting points for further research than definitive statements on the topic. Nevertheless, with this general and rough outline as our guide, we can begin to examine features of ethnic politics in post-Suharto Indonesia.

\section{Politicization and mobilization of ethnicity peaked during the democratic transition but subsequently declined.}

In dramatic comparison to the Suharto years, during the height of Indonesia's democratic transition (1998-2001) politicization of ethnicity occurred with sometimes startling speed and ferocity. The chief expressions of 
ethnic politics, more or less in the chronological order in which they appeared, are described in the following sections.

Violent ethnic conflict. In some parts of Indonesia, violent movements mobilized against ethnic adversaries, whether these adversaries were rival communities (as in communal conflicts in West and Central Kalimantan and North Maluku) or the state (as in separatist movements in Aceh and Papua). These violent conflicts have attracted by far the most scholarly attention of all ethnic political phenomena in post-Suharto Indonesia (e.g., Bertrand 2004; van Klinken 2007; Davidson 2008; Wilson 2008; Drexler 2008; Aspinall 2009b), but they occurred in only eight out of Indonesia's thirty-three provinces, where only 7.5 percent of the total Indonesian population live. In a slightly different category, ethnic militias or organizations of preman (gangsters) also emerged or strengthened in many provinces, though typically their targets were rivals in protection rackets and other illegal businesses rather than ethnic publics or state authorities (Brown and Wilson 2007; Tajima 2004). In some places, ethnic militias did mobilize against minority communities, as when "traditional" village security forces targeted migrants in Bali (Schulte Nordholt 2007, 30-40).

Formation of ethnic political movements and organizations and assertion of ethnic demands. There was also an efflorescence of ethnic political and civil society organizations of various sorts, from the ethnic militias and separatist groups mentioned earlier to ethnic associations and selfhelp groups (especially of migrants) and nongovernmental organizations (NGOs) advocating the rights or promoting the culture of this or that ethnic group (e.g., Schiller 2007; van Klinken 2008). In many areas, there were also assertions of ethnic prerogatives, such as the emergence of movements calling for preferential treatment for putra daerah (sons of the region) rather than migrants from other parts of Indonesia in employment, access to government contracts, and other economic opportunities (Diprose 2002).

Redrawing of administrative boundaries along ethnic lines. In a process known as pemekaran (blossoming) the number of administrative regions in Indonesia has proliferated, with provinces increasing from twenty-six to thirty-three and districts jumping from 341 when Indonesia democratized to approximately 500 by mid- $2010 .^{3}$ Local elites who sought regions of their own to dominate were often the driving force in the creation of these new provinces and districts; they often did so by mobilizing ethnic claims and depicting a new administrative region as a solution to 
historical discrimination against a particular group or as an ethnic homeland (Schulte Nordholt and van Klinken 2007; Kimura 2010).

Revival or reinvention of traditional ethnic political institutions and mobilization of ethnic discourse in contests for political power. Throughout Indonesia there has been a notable "revival of tradition" (Henley and Davidson 2007) involving varied attempts to resuscitate customary institutions and law (adat) in ways that are invariably - but not always straightforwardly - associated with particular ethnic identities (e.g., Avonius 2003; Duncan 2009; Henley and Davidson 2007; Li 2007). This revival of the local has permeated political life as, for example, when local elites evoke adat and ethnicity to demonstrate "their fitness to rule" ( $\mathrm{Li}$ 2007, 359) when competing in electoral contests.

Jacques Bertrand's formulation of why this invigoration of ethnic politics coincided with democratization remains the most convincing general explanation: "The late 1990s constituted a critical juncture in Indonesia's postindependence history, during which institutional transformation opened up channels to renegotiate the elements of the national model" (Bertrand 2004, 3; also see Bertrand 2008). Ethnic groups-or political entrepreneurs claiming to be representatives of ethnic groups-saw in the post-Suharto political flux opportunities to press their claims and advance their interests. Some groups did so violently, whereas others tried to operate within, or to amend (as by pemekaran), existing political institutions.

The order in which the four categories of ethnic politics have been presented describes a rough arc, a shift from the raw, unmediated, and often violent conflict of the early transition to the institutionalization and taming of conflict later on. Where ethnic identity was initially mobilized in violent contests for political power, it was later more often evoked in peaceful contests through the ballot box. Violence peaked early and declined rapidly thereafter: according to the most comprehensive database to date, annual conflict deaths went from 51 in 1996 to a peak of 3,546 in 1999, and declined to 111 in 2003 (Varshney, Panggabean, and Tadjoeddin 2004,23$){ }^{4}$ In some places, ethnic identity politics gave rise to new institutions (such as new districts or local political parties in Aceh) or to new political traditions (such as political dominance by Dayaks in certain provinces in Kalimantan). But in few places do ethnic politics now constitute an organizing framework for political life. Overall, with the passing of the furies that accompanied Suharto's fall, ethnicity is becoming less important in Indonesian politics, not more, as I demonstrate in the remainder of this article. 


\section{Indonesia is a weakly ethnicized polity.}

Because of widespread and sometimes intense ethnic mobilization during the political transition, a new conventional wisdom seems to be seeping into literature on Indonesian politics: that a shared civic nationalist framework for political life has been significantly challenged by the rise of localism, ethnic politics, and other forms of particularism (e.g., Schulte Nordholt 2008). Yet viewed in comparative terms, Indonesia remains a polity in which ethnicity plays a surprisingly minimal role in politics. Consider the following elementary features of Indonesian politics.

Absence of ethnic and regional parties. Early in the political transition, Indonesia's leaders made the consequential decision to require all parties that wished to contest legislative elections to demonstrate that they had a broad nationwide presence. This move effectively precluded the formation of local or regional political parties and subsequently greatly restricted the role played by ethnic identity in official politics. Even at the local level, contestants for seats in local legislatures are required to affiliate with one of the national parties and thus identify themselves, however minimally, with national rather than local concerns. Here and there, particular national parties become vehicles for particular ethnic groups in particular districts, but this happens on an ad hoc basis, and it is all but impossible to point to broad patterns. In this regard, Indonesia stands in obvious contrast to countries like Malaysia, Sri Lanka, and (even) India, which, while they are no more ethnically diverse than Indonesia, have party systems that are to varying degrees structured around ethnic or communal identities.

Weak institutionalization of ethnicity in subnational units. To a large degree, ethnicity is also not institutionalized in the subnational governments (provinces and districts). As Robert Cribb $(1999,175)$ has noted, few provinces are "both ethnically relatively coherent and more or less coterminous with the local dominant ethnic group," and most of them are not portrayed by officials as being ethnic homelands. This has changed only a little as a result of pemekaran, with the most significant changes at the district level. Moreover, Indonesian provinces and districts lack the attributes we associate with ethnofederal or similar models of state organization: official languages, separate citizen identification papers, distinctive school curriculums, or other methods by which distinctive territorialized ethnic identities may be inculcated in citizens.

Weakness of ethnic voting patterns. It makes little sense to speak of ethnic voting blocs at the national level in Indonesia. Not only are there no 
local or ethnic parties in national contests (even those in Aceh cannot compete for seats in the national legislature), but major national surveys, notably those conducted by the Lembaga Survei Indonesia (Indonesian Survey Institute) show that ethnic background has very little impact on party choice and virtually no influence at all in presidential elections (Liddle and Mujani 2007, 849-850; Liddle and Mujani 2010). As we shall see, ethnic factors count in voting at the local level-especially in elections for regional government heads - but even here ethnic factors are rarely a trump card. Most scholarly analyses of elections for local government heads thus focus little on ethnicity and point to other factors, such as performance, program, media campaigns, and links to local power structures, in explaining candidate success (Erb and Sulistiyanto 2009).

\section{Nevertheless ethnicity counts: soft ethnic politics is prevalent in local contests for government power.}

Despite the overall decline in ethnic political mobilization, ethnic identity still counts in Indonesian politics. The continuing political relevance of ethnicity can be illustrated by three features of contemporary electoral politics, with a particular focus on the dynamics of direct elections of local government heads (known in Indonesian by the acronym pilkada). These were introduced in 2005 to replace an earlier form of indirect elections by which government heads were chosen by local parliaments, but which had become discredited by pervasive "money politics." Significantly for our purposes, in these direct elections not only heads of local governments (provincial governors and district heads) are directly elected by voters, but so too are their deputies, with candidates running together as pairs.

Mobilization of ethnic symbols and appeals in political contests. Due to a proliferation of case studies of pilkada, we now have much evidence that the mobilization of ethnic symbols and appeals is pervasive in elections for local political office. Throughout the country, pilkada candidates routinely include adat performances and ceremonies in their campaigns, make speeches in local languages, wear traditional costumes, and otherwise invoke local traditions and cultures to increase their electability (see Duncan 2009, 1092, on elections in Tobelo, North Maluku; Vel 2005 on East Sumba; Buehler 2009 on Pangkep and Soppeng in South Sulawesi). To the extent that such cultural symbols and appeals are associated with particular ethnic identities, it is possible to see ethnicity as virtually everywhere, as pervading Indonesian politics thoroughly. However, typically such campaigns involve a soft form of ethnic 
mobilization that aims simply to provide candidates with claims to local authenticity and does not appeal to a sense of ethnic grievance nor even explicitly highlight ethnic difference. ${ }^{5}$

Importance of ethnic identity in voter choice. Here, evidence is not clearcut, but it seems that ethnicity is an important background factor in determining how people vote in contests for local executive power (in contrast to voting in national contests where, as explained earlier, ethnic voting is very weak). There is some opinion polling that suggests that voters are less likely to vote for candidates from another ethnic group, especially when their own group is a large one and if there has been a history of ethnic conflict in the territory concerned. Thus, in West Kalimantan, pollsters from Lingkaran Survei Indonesia (Indonesian Survey Circle) found that people were generally unwilling to vote for a gubernatorial candidate from a different ethnic group than themselves. In South Sulawesi, voters were somewhat less concerned about the ethnic identity of candidates, and much less so in Bangka Belitung, where an ethnic Chinese contender came in second and attracted significant support beyond the ethnic Chinese community (Lingkaran Survei Indonesia 2008).

Though systematic evidence is yet to be put together, available observations would suggest that since democratization, and especially since the introduction of direct local government head elections, there has been a shift in favor of alignment between the ethnic identity of local government heads and the local populations they govern. Electoral winners tend to be drawn from the largest ethnic group in the district or province concerned (though there are still exceptions). This contrasts with the authoritarian period, when nonnative sons were sometimes appointed as regional heads (especially in Kalimantan and Sumatra). This shift is particularly important in areas such as West Kalimantan, where large indigenous groups were previously underrepresented in local politics but where now "the Dayaks have been successful in their endeavor to assume bupati-ships in West Kalimantan, particularly in the kabupaten which are predominantly Dayak and non-Muslim" (Subianto 2009, 333). Throughout Indonesia, in conjunction with pemekaran, this trend has resulted in elites from ethnic groups that previously saw themselves as politically or socially marginalized now ruling their "own" districts or provinces.

The importance of ethnic identity for candidate selection and strategies. The weak evidence we have about the ethnic preferences of voters is mirrored by an even stronger conventional wisdom among candidates 
themselves that ethnicity is an important factor in guaranteeing electoral success. There is a widespread recognition that among candidates it is important to be a "local son from the right ethnic group" (Smith 2009, 322). Leading national politicians from parties such as PDI-P (Indonesia Democracy Party-Struggle) and Golkar whom I interviewed recognize that it is essential to choose candidates for local government office who are members of the majority ethnic group in the region concerned (a trend that is itself reinforced by the growing reliance by political parties on opinion polling to select their candidates), although they often regret this necessity as signifying a diminution of the force of Indonesian nationalism. At the practical level, when it comes to building political networks and campaign teams, political aspirants also believe that ethnic symbols and appeals can be used to mobilize support. However, when political candidates speak of such matters, they typically use a language of rational and even cynical calculation rather than one of impassioned entitlement. As one (ethnic Javanese and ultimately unsuccessful) candidate for the North Sumatra governorship put it about his chances, "The use of Javanese symbols will be effective to win support from 4.2 million Javanese descendants in the eastern coast of the province."

We can thus see that ethnic identity is far from irrelevant in the new local politics of Indonesia. On the contrary, it is fundamental. But it takes a soft form, narrowing the range of possible occupants of key political posts and supplying a new range of symbols that must be mobilized in contests for political power. Indonesia is not a country where, to draw once more on Esman (1994, 27), political contestants "combat ethnic antagonists" or "impress ethnically defined interests" on the state. Political contestants in Indonesia frequently signal their ethnic identity, but they rarely represent themselves exclusively as defenders (or opponents) of the interests of any specific group, even implicitly.

\section{Ethnic politics generally lack ideological depth.}

As noted earlier, most literature on ethnic politics in Indonesia focuses on the relatively rare cases of violence or dramatic demands for ethnic exclusivism. Authors who have looked for ethnic conflict and ideologies have found them (I include myself in this group: Aspinall 2009b). Overall, however, a striking feature of much of what passes as ethnic politics in Indonesia is its superficiality. The appeals to ethnic symbols and identities politicians make in elections are usually formulaic and shallow, the revival of adat institutions halfhearted and formalistic, the calls for special treatment for putra daerah (regional sons) often unheeded, and while 
local cultural revivals sometimes attract interest among local officials, bureaucrats, and déclassé aristocrats, they frequently fail to attract wider attention. With few exceptions, Indonesia is a country of dabblers in ethnic politics, not ideologues. Very often, when political contestants talk about ethnicity, they are both frankly calculating and brutally dismissive, admitting that ethnic appeals can help but are not crucial.

One area where we can test the ideational depth of the new ethnic politics is education reform. Battles over education are often central to ethnic conflict, with rival groups frequently disagreeing over curriculum on sensitive topics like national and local history or language of instruction. In Indonesia, around the time of the fall of Suharto and subsequent calls for decentralization, the education system was often a target of criticism for being insufficiently sensitive to local culture and aspirations. Decentralization of education policies introduced in 2003 subsequently allowed district governments to have greater say on "local content" ( $\mathrm{mu}$ atan lokal) at primary and secondary levels, expanding on earlier provisions introduced in the late Suharto years.

Since that time, local governments in some regions have begun to use these provisions to increase teaching of local culture and traditions. Dayak culture, for example, features prominently in local content plans in parts of Kalimantan. ${ }^{7}$ However, just as frequently, topics like English language, business skills, environmental awareness, and the like are emphasized. One study of this matter has been conducted by Carole Faucher (2007; see also Faucher 2006), who looks at local curriculum design in Riau Archipelago province, one site of a post-Suharto Malay cultural revival. She finds that the new rules have not led to a significant increase in local cultural material. For example, in Tanjungpinang, the three local subjects are computer science, home economics, and Arab Melayu, with this last topic having already been offered as an elective before decentralization of curriculum. In fact, she observes, "very little attention is paid to local Malay history" and "textbooks that deal explicitly with the local Malay heritage are scarce as well" (Faucher 2007, 454). Faucher $(2007,455)$ argues that despite decentralized education, "the presence of the local is weak, [and] the impact of the nation-state is strong." The youth of the province are constantly exposed to national media and pop culture and see Jakarta as a symbol of urban modernity while associating Malayness with backwardness. Faucher concludes that attempts to "revive, invent and rephrase notions of Malayness" in the region were mostly an effort of the older elites and were less appealing to the younger generation, who were more oriented to the national capital (Faucher 2007, 457). More research is needed to ascertain national trends with certainty, 
but preliminary observations suggest that the apparent resurgence of localism and ethnic identity politics in post-Suharto Indonesia sent out only feeble ideational and cultural roots.

\section{Ethnic organizations have little political impact.}

Ethnic organizations proliferated during Indonesia's democratic transition. As well as a large number of NGOs and associations promoting indigenous rights or cultural revival in various regions, numerous ethnic militias or preman organizations emerged. Ethnic associations of various sorts, especially cultural and self-help groups of migrants in ethnically heterogeneous provinces in Kalimantan and Sumatra, many of which had existed for decades, also appeared to play important brokerage roles in elections. Nankyung Choi, for instance, argues that the large migrant population in the Riau archipelago meant regional organizations, such as the Keluarga Besar Sumatra Utara (North Sumatran Big Family), have extra influence in direct local government elections and take on "the role usually played by village leaders" (Choi 2007, 336), directing their members to vote for particular candidates.

In fact, the political influence of most ethnic organizations is limited. Take ethnic gangs and militias. There is no doubt that in some localities these organizations have become important players in criminal underworlds and protection rackets. David Brown and Ian Wilson (2007), for instance, chart the rise of the Forum Betawi Rembug (FBR, Betawi Brotherhood Forum) to the status of the most important preman organization in Jakarta; Laurens Bakker (2008) explains how Dayak militias in East Kalimantan use their authority as defenders of adat to negotiate deals between mining companies and communities in land disputes. But the influence of such violent groups has been limited to such realms. Ian Wilson (2010) argues that many of the preman groups that emerged as violent political players from the late 1990s have become increasingly domesticated by democratization, with their leaders either seeking political office via established parties or forming parties of their own. The latter course has been a spectacular failure, and individual ethnic gang leaders who seemed to enjoy significant political clout have also fared badly when contesting popular votes: Fadloli el-Muhir, the leader of FBR, ran for a DPD (Regional Representatives Council) seat in Jakarta in 2004 but came in seventh with 224,299 votes, only a little more than the claimed FBR membership of 200,000 (Wilson 2010, 212). In short, despite claims that ethnic and other gangs were becoming dominant players in local politics (e.g., Hadiz 2003), their prominence increasingly appears 
to have been an epiphenomenon of the democratic transition rather than a permanent and powerful feature of Indonesian political life.

Likewise, even the largest ethnic associations appear to have little ability to deliver blocs of voters in elections. This has been demonstrated by Gerry van Klinken (2008) in his analysis of one of the largest ethnoregional organizations in Indonesia-Kerukunan Keluarga Sulawesi Selatan (KKSS, South Sulawesi Family Association). As a social organization, KKSS is successful: it boasts a large and loyal membership, offers a range of services for members across the archipelago, and maintains a network of patronage that cuts across class differences. During the political transition, KKSS increased its political profile, publically supporting candidates and organizing fundraising events for national and local elections. However, van Klinken $(2008,54)$ explains that as a political force, KKSS has "consistently failed," and he provides several examples of where KKSS has backed losing candidates in local elections. $\mathrm{He}$ argues that ethnoregional organizations like KKSS cannot mobilize ethnic voting blocs, in part because it is "difficult to scale up from the local clientelist ethnic protection rackets and village-level solidarities ... [to an entire] ethnic group in a given district or province.... Voters, free to choose in secret, think more pragmatically than their ethnic patrons like to imagine" (van Klinken 2008, 56). There are "competing clientist networks" and a diverse range of interests influencing voters' choices, with ethnic patronage being but one among many (van Klinken 2008, 57).

Similar conclusions can be drawn from other parts of Indonesia. Take, for example, Javanese ethnic organizations in North Sumatra, a province where the population is about one-third Javanese. According to one participant, there are about thirty-six ethnic Javanese organizations in North Sumatra (interview, Medan, October 29, 2009). Many are small cultural organizations, and some mobilize only around election times. Many of them have split off from the major and longest-established such group, Putra Jawa Kelahiran Sumatera (Sons of Java Born in Sumatra, Pujakesuma). But in interviews, leaders of these organizations are themselves skeptical of their influence and are not convinced that Javanese ethnicity or organizations make a big difference politically. According to Choking Susilo Sakeh of Pujakesuma, there has been a growth in Javanese and other ethnic organizations in the post-Suharto period in North Sumatra, and most back candidates in local elections, but their "longing" to play a role in elections has had little effect (interview, Medan, October 12, 2009). Ruslan of another Javanese group, Persatuan Pemuda Jawa (Pendawa, Association of Javanese Youth), said that during the gubernatorial election in 2008, the different Javanese groups threw their support 
behind different candidate pairs. Djamin Sumitro of Forum Komunikasi Warga Jawa (FKWJ, Javanese Residents' Communication Forum) says many such groups are just looking for money from candidates (interview, Medan, October 13, 2009). In conclusion, it appears obvious that ethnic political organizations are not strong actors and that they lack the power to significantly influence, let along determine, the shape of politics throughout much of Indonesia. Their dominant pattern of political activity is inconsequential patronage hunting rather than powerful ethnic mobilization.

\section{While democratization heightened ethnic conflict, consolidation of democracy has prompted interethnic cooperation and moderation.}

If during the democratic transition there was a sharpening of ethnic identity and radicalization of ethnic demands in some areas, during the subsequent period of democratic consolidation and normalization since about 2001, the pattern has been the reverse. Rather than ethnic outbidding or conflict between rival ethnic voting blocs, the general pattern has been one of interethnic bargaining, cooperation, and moderation.

As some analysts have noted, candidates for political office in Indonesia who emphasize exclusivist ethnic programs have almost invariably been defeated, such as Professor Usop (a Dayak chauvinist and ethnic cleanser of Madurese) in Central Kalimantan or Lukas Enembe (a fiery advocate of highlanders' rights) in Papua (Mietzner 2006, 2009). Overall, Indonesian electorates do not support ethnic exclusivists, and most winning candidates are those who appeal "to cross-cultural constituencies instead of relying on support by one ethnic, religious or social group" (Mietzner 2009, 277).

One factor facilitating cooperation is the requirement that candidates for local government head and deputy head positions be nominated together as pairs. It has become a new political norm in ethnically diverse provinces and districts for ethnically diverse tickets to run for these positions. Thus, most tickets for the governorship and deputy governorship in West Kalimantan consist of a Malay paired with a Dayak, in West Nusa Tenggara they are Sasaks (the largest ethnic group in Lombok) paired with candidates from Bima in Sumbawa ${ }^{8}$, and so on. This pattern also applies in former conflict areas like Poso, Central Sulawesi (Diprose 2006), or Maluku where, in the gubernatorial elections of 2008, each candidate ran with a deputy from another ethnic and/or religious group. In Maluku, this approach prevented "ethnic exclusivism at the elite level" (Tomsa 2009, 256) and helped facilitate a peaceful election. In West 
Kalimantan, all but one of the successful pairs in district elections in 2005 were from different ethnic groups (Dayaks and Malays, or Dayaks and Chinese); the other pair united a Christian and a Muslim Dayak (Subianto 2009, 347). Though sometimes this approach is presented as a peacebuilding measure, the calculations are typically practical. As one member of the Prosperous Justice Party (PKS) in North Sumatra explains, "If [the running mates] are both Mandailing, if they're both Javanese, they aren't going to win ... homogeneous pairs can lose. They [the political parties] don't take that risk" (interview, Medan, October 28, 2009).

An additional feature of most electoral politics in Indonesia is the climate of deliberately constructed ethnic harmony in which most contests are conducted. Writing on political dynamics in Minahasa in Northern Sulawesi and the ability of the region to escape the ethnic conflict that occurred in nearby parts of Indonesia during the post-Suharto transition, David Henley, Maria Schouten, and Alex Ulaen $(2007,324)$ describe the language of local politicians as "Minahasan neo-Pancasilaism," because its emphasis on "harmony and inclusion is partly an oblique confirmation that the potential for discord is strong." Yet a similar stress on harmony and unity occurs in most electoral contests in Indonesia, arising perhaps partly from a legacy of earlier generations of nation building and official ideology, but also from electoral calculations. In describing themselves, candidates for political office across the country routinely use phrases such as Sahabat semua suku (friend of all ethnic groups), the slogan of Syamsul Arifin, the victorious candidate for governor of North Sumatra in 2008, or Keberagaman itu indah (diversity is beautiful), favored in this case by Haji Ipong Muchlisoni, an ethnic Javanese and second-place candidate in the 2010 mayoral election in Samarinda, East Kalimantan.

The campaign activities of candidates are often in keeping with their slogans. Take, for example, the aforementioned Haji Ipong Muchlisoni:

Ipong's schedule is full of visits to various communities around Samarinda, sometimes for only ten minutes, visiting seven to nine different places in a day. He meets with arisan [communal savings groups], pengajian [prayer meetings], paguyuban [associations]—any organization with a group.... The groups are often only ten or twenty people, sometimes up to 200. His visits have included an appearance at the funeral of a respected local leader from Tana Toraja [a region in South Sulawesi province], church visits, and an appearance at a gospelsinging contest bringing competitors from across the archipelago. Arsinah Sadar and Ibnu, both part of Ipong's campaign team, said that ethnic approaches were certainly an influencing factor, especially for reaching lower and middle class voters. ${ }^{10}$ 
Likewise, Syamsul Arifin, the victor in North Sumatra, who is ethnically Malay, used a variety of approaches to attract Batak voters: in rallies in Tapanuli, for example, he wore an ulos, a Batak shawl. He was given the title of Raja Batak or Batak chief (Sinar Indonesia Baru, May 26, 2007). During his campaign, Syamsul also attended events targeting ethnic Chinese voters; in one such event he emphasized the need for coalitions across ethnic lines. As a report on the event recounted, one ethnic Chinese supporter of Syamsul emphasized that he was "aware that he and other ethnic Chinese cannot act without support from other ethnic groups." summary, although some scholars suggest that voting in ethnically divided societies tends to produce a "race to the extremes" (Collier 2010, 56 ), the Indonesian pattern has been the exact opposite: in most Indonesian elections, ethnic coalition building, not ethnic outbidding, is the norm.

\section{Democratic politics have tended to fragment rather than consolidate or aggregate ethnic identities.}

Indonesia entered its democratic transition with a history of repression of ethnic political organization and little formal recognition of ethnicity in the political system. The scattered violent conflicts that occurred early in the democratic transition seemed to portend a society increasingly divided along ethnic lines. However, the institutional changes that occurred as part of democratization tended to fragment ethnicity into a mosaiclike pattern, with a multitude of tiny tiles of irregular size and shape and varying colors, rather than a checkerboard of clearly distinguishable and large ethnic blocs. This process of fragmentation has occurred as a result of three institutional changes: decentralization, administrative fragmentation, and elections.

Decentralization of political and fiscal authority to the second-level administrative units (districts) rather than the provinces was a decision taken early in Indonesia's transition, and a hugely consequential one. As many studies show, decentralization had the early effect of heightening communal, including ethnic, conflict at the local level because it shifted state resources-and hence the focus of political contestation-down toward the base of the political system. However, this shift tended not only to localize political conflict and competition, but also to fragment it. One important goal of the policy of devolving power to districts was to ensure that the subnational units empowered by decentralization would not be large enough to challenge the center or consider secession (Rasyid 2003, 63). A by-product of the policy was to fracture large-scale ethnic identities: when the key political contests are for the leadership of regions with hundreds of thousands of residents, little political advantage is conferred 
by thinking in ethnic categories that encompass millions or tens of millions of people. Decentralization to the district level thus did not remove ethnicity from politics, but it did undercut its ability to play a significant role in national politics.

Pemekaran, or the fragmentation of administrative regions into smaller units, reinforced this trend. Like decentralization, pemekaran did not deactivate or demobilize ethnic identities, at least in its early stages. On the contrary, as already suggested, movements in favor of the establishment of new administrative regions (provinces and districts) sometimes involved passionate and violent mobilization (e.g., ICG 2005). However, the evidence so far suggests that, with some exceptions, the overall intensity of ethnic mobilization declined in most new districts and provinces to emerge out of pemekaran. Aspiring heads of regional government often mobilized ethnicity strongly in campaigns to establish new districts or provinces, but once that goal was achieved, erstwhile leaders of the pemekaran movement typically settled back to enjoy the fruits of their achievement, or fell out among themselves.

But the important effect was fragmentation. Neither decentralization nor pemekaran in itself reduced the overall salience of ethnic identity in politics; arguably, each increased it, at least initially. But by refracting ethnicity toward the base of the political system, they blunted its intensity. In Indonesia, political movements claiming to represent smaller ethnic identity groups tend to mobilize around less ideologically coherent ethnic claims, be less inclined to see themselves in absolutist terms and more inclined to see themselves as part of a wider universe of relevant groups and not merely or mainly defined against a single adversary. The shift of the locus of intergroup conflict to smaller population units also reduced the likelihood that ethnic contenders would imagine themselves as potentially state-challenging or be attracted to insurgency or secession. Moreover, as we move down in geographical scale, ethnicity gives way to other identities - clan or kinship, hometown, or home villagewhere, while passions are not always less intense, they are harder to scale up into the political system. There are exceptions, but such has been the overall Indonesian pattern.

Electoral politics produced a similar logic, with electoral competition now taking place not only in contexts of ethnic pluralism, leading to the tendency of alliance building identified in the preceding discussion, but also occurring within populations that ethnic entrepreneurs had previously tried to define against larger and threatening Others. The outcome has been further fragmentation, as has been particularly obvious in local elections in Aceh and Papua (Mietzner 2007), the two provinces of Indonesia where-once East Timor became independent after 1999- 
ethnonationalist and secessionist movements were strongest. This phenomenon was driven home to me in dramatic fashion in mid-2007 when I witnessed a campaign event for the district head election in the Kluet Valley in the district of South Aceh, in which the candidate was a former local leader of the Acehnese ethnonationalist guerrilla organization Gerakan Aceh Merdeka (GAM, Free Aceh Movement). In his campaign speech, the candidate referenced symbols and themes of GAM's former struggle, but his emphasis was that it was now time for a "son of Kluet" to rule South Aceh because the district had been for far too long neglected by "officials in Banda Aceh" (not, it should be noted, in Jakarta). His comment was doubly significant because a GAM-affiliated governor was by this time already in power in Banda Aceh. Likewise, in Papua, writes Marcus Mietzner (2009, 267), elections for local government office highlighted not only "obvious socio-ethnic fragmentation" but also distinctions between "tribes and clans," with the result that they undercut "the very concept of pan-Papuan unity that had so far formed the backbone of the separatist agenda" (Mietzner 2009, 279).

\section{Patronage trumps ethnicity in Indonesian politics.}

Although ethnicity is politically relevant in most regions, most detailed local studies suggest that it does not provide the ideological or organizational framework that structures local political dynamics. The most consequential frameworks for organizing political life-for determining who wins elections, who gets access to scarce state resources, who has influence over policy and the like-are based on patronage and clientelism. Sometimes these patron-client networks are rooted in, or coincide with, particular ethnic or subethnic identities. Typically, however, they infuse and cross virtually all forms of social and political organization: political parties, social and religious associations of various kinds, bureaucratic and business networks and organizations, and ties loosely based on family, clan, kinship, and region. Political contenders who succeed are typically those who manage to forge broad networks cutting across as many such organizational chains as possible. Those who build their political support narrowly, on the basis of a single identity claim, tend to lose out. In other words, ethnic affiliations and organizations are grist for the patronage mill, but they are only one small part of the grist that is available.

This conclusion is confirmed by a survey of electoral politics. Political contestants in local contests across the country often say that ethnicity is not a trump card and that what really counts is membangun jaringan (building networks). To succeed, candidates typically try to 
build support among as many sorts of organizations and brokers as they can. Thus, in a multiethnic city like Medan, candidates try to win endorsement by ethnic power brokers and organizations, but they also woo business, bureaucrats, preman organizations, and the like. In Dirk Tomsa's study of the 2008 gubernatorial election in Maluku (Tomsa 2009), Karel Ralahalu's success was a consequence of his ability to forge patronage networks within business, the bureaucracy, and ethnoregional community organizations. His charisma and well-crafted image as a "man of the people" with close ties to village communities was also essential to his popular appeal. Indeed, he built clientelistic links with various community organizations, and he also sponsored new organizations such as the Majelis Latupati (an organization of adat leaders) through which he could engage village leaders and expand his patronage network.

What sometimes appears on the surface as ethnic voting in Indonesia is often merely a by-product of the social embeddedness of patronage networks. A growing body of literature on Indonesian elections emphasizes the key role played by local, especially village-level, brokers and tokoh masyarakat (community leaders), such as village heads, in mobilizing votes at the local level, often in exchange for or with the promise of material reward (Fauzan 2009; Clark and Palmer 2008; Palmer 2010; Tomsa 2009). A candidate's network of local brokers will tend to be strongest in his or her hometown, district, or subdistrict, with the result that even otherwise unsuccessful candidates often win handsomely in their local area, giving the appearance of ethnic voting. Yet although such campaigns draw on local networks and are presented in a cultural idiom that is familiar to voters, they frequently have very little to do with the social mobilization of difference that is so central to ethnicity.

In some settings, patronage undergirds ethnic politics: Chandra $(2004,12)$, for example, argues that ethnic voting arises in India's "patronage democracy" because a typical voter will expect to "obtain the greatest material and psychic satisfaction from individual elites from her 'own' ethnic group who occupy elected office." In Indonesia, it has been argued persuasively that battles for control of the patronage resources of the state were at the heart of the bitter communal conflicts of the early post-Suharto period (van Klinken 2007). ${ }^{12}$ There are indications here and there that patronage is distributed along ethnic lines in some Indonesian regions (such as in accusations of Makian dominance of the bureaucracy in North Maluku [ICG 2009, 7-8]). As already noted, in many parts of Indonesia early on in the transition, local politicians made promises of preferential treatment of "native sons" in government employment and business. Overall, however, there seems to be relatively little of this going on ten years into the democratic transition. Interviews with contractors 
in East Kalimantan and North Sumatra, for example, suggest that ethnic identity is rarely a factor in determining how the crucial good of public construction contracts is handed out; public service positions in most regions still tend to be sold to the highest bidder rather than distributed along ethnic lines (Kristiansen and Ramli 2006). Here and there scraps of patronage resources are available to those who organize along ethnic lines-for example, ethnic militias who act as brokers in land conflicts in East Kalimantan (Bakker 2008) - but this is a tactic of those who are trying to muscle in from outside, not of those who are embedded in the heart of the system. At most, ethnicity is of secondary importance in the patronage networks that surround and suffuse the Indonesian state.

Even more than this, it seems possible to view patronage distribution as facilitating the interethnic coalitions and cooperation that have become so characteristic of Indonesia's local politics over the last halfdecade. In the electoral arena, patronage is often the lubricant that smoothes the formation of candidate-pair coalitions and draws ethnic community leaders to endorse candidates from outside their own group. Anecdotal evidence also suggests that distribution of patronage among ethnic community leaders and their clients is a crucial mechanism for preempting or resolving violent conflict. For example, following violence between Tidung and Bugis actors in Tarakan, East Kalimantan, in September 2010, new deals were struck between leaders of ethnic associations and militias about access to legal and illegal business in the city. Distribution of construction contracts and other economic resources to former combatants has been important in facilitating social peace in the aftermath of major separatist and communal conflicts such as those in Aceh and Poso, Central Sulawesi (Aspinall 2009a; McRae 2010). The ubiquity of corruption and patronage has certainly had deleterious effects on the quality of governance in Indonesia's new democracy, but arguably they have also played an important role in blunting the social and political conflicts that accompanied the democratic transition, including in the ethnic arena (for more general applications of these arguments, see Dick and Mulholland 2011; Aspinall 2010).

\section{There are exceptions: where claims of indigeneity are welded into an ethnic political ideology, ethnic politics are likely to be more lasting and consequential.}

We should not be Panglossian about the decline of ethnic politics in Indonesia. Overall, ethnicity remains more important in public life than under authoritarianism. In particular, in areas that experienced violent 
conflict in 1997-2001, before the moderating effects of institutional reform came into effect, memories of those conflicts still hang not far below the surface of political life (although in many cases the effect seems to make local politicians and voting publics especially anxious to promote interethnic cooperation). In the separatist provinces of Aceh, Papua, and West Papua, local identity has come to be crystallized in political institutions that distinguish these regions from other parts of Indonesia. These institutions include local political parties in Aceh (the only place in Indonesia where such parties may contest elections), a Papuan People's Council (Majelis Rakyat Papua) open only to indigenous Papuans, and special indigeneity requirements for candidates for local government office in Papua and West Papua. These institutions will help to maintain a special salience for ethnic difference in local politics in these places, adding to the already powerful effects of traumatic memories of past conflicts and deeply embedded popular ideologies of ethnonationalism. In other parts of Indonesia where awareness of indigenous status has become politicized and overlaid with a sense of grievance about encroachments by migrants and with a sense of political entitlement - with Dayak identity in various provinces of Kalimantan being perhaps the prototypical example-ethnicity will likely remain an important factor in local politics. But such places are the exceptions to the general rule of soft ethnic identity politics that predominates in most of Indonesia.

\section{Conclusion}

Indonesia is not unique in experiencing increased political mobilization of ethnic identity during a democratic transition and a decline thereafter. To some degree, the decline is part of a wider deescalation of social movements and contentious politics that has occurred as the uncertainty of the democratic transition has passed, giving way to the consolidation of a new political order (Aspinall 2005). Nor has ethnicity entirely disappeared from Indonesia's political map. On the contrary, it is now visible virtually everywhere and is much more important politically than it was prior to the democratic transition. Nevertheless, overall there has been a dramatic decline in its political salience. Predictions that Indonesia might experience an "ethnification of the nation" (Jacobsen 2000) and a breakdown of "a shared sense of Indonesian citizenship" (Schulte Nordholt 2008, 2) have not come to pass.

Although there are places in Indonesia where ethnicity is now central to local politics, there are whole regions of the country where it rests 
lightly on political life. This applies both to regions where populations are relatively ethnically homogenous, especially in the Javanese heartland, and to places where there are mixed populations-notably large swaths of Sumatra, Kalimantan, and Sulawesi, with big and well-established Malay, Bugis, and Javanese diasporic populations. In many such places, ethnicity still counts: voters have a general preference for supporting political candidates from their own group, parties take this preference into account when selecting their candidates, and political contenders make ritual obeisance to ethnic cultural symbols and organizations. But ethnicity seems to play little consequential political role beyond that. Indonesia is a weakly ethnicized polity overall. Ethnic categories are used little to allocate state resources. Soft rather than hard ethnic politics is the predominant pattern, with ethnic symbols mobilized in political campaigns but not in zero-sum contests between ethnic antagonists.

My goal in writing this article was to identify, in a preliminary and exploratory way, general features of ethnic politics in Indonesia. Nevertheless, in concluding such an overview, it is appropriate to review causal factors that explain the limited influence of ethnicity in post-Suharto politics and, in doing so, to highlight potentially rewarding areas for future scholarship. Three factors appear to be especially significant.

First, and with greatest potential for comparative scholarship, we can point to institutional factors. Many of the most telling analyses of highly ethnicized polities point to the institutionalization of ethnic identity in political structures, especially in party systems and state structures (e.g., DeVotta 2005). In Indonesia, the decision early in the democratic transition to disallow local political parties from contesting elections was, it now appears in retrospect, highly consequential. It meant that the elevated levels of ethnic identification in politics that accompanied the transition were not crystallized, captured, and perpetuated in political movements that themselves sought to seek state power. At the very least, the decision placed an additional layer of brokerage and negotiation between ethnic leaders and state institutions. Indonesia's national political parties, though derided as poorly institutionalized vehicles of oligarchic interest, have proven remarkably adept at encouraging cross-ethnic bargaining and in minimizing the role of ethnicity in politics. ${ }^{13}$ Other institutional reforms, such as the devolution of political power to the district rather than provincial level and the fragmentation of local governments, have also helped to shatter ethnic identities, refracting ethnic tensions to lower levels of society during the transition, but preventing them from gaining a foothold in national politics after it. There are comparative lessons here for scholars interested in how political institutions may ameliorate ethnic 
conflict—lessons about institutional design and about sequencing and timing. ${ }^{14}$

Second, and arguably most important of all, is the historical legacy of the tradition of Indonesian national identity. Since the early twentieth century, Indonesian nationalists have emphasized the imperative of national unity, first in the face of what they saw as Dutch attempts to divide and weaken Indonesians, and later against separatist and localist challenges to the national state. During the Sukarno-and especially the Suharto-years, this civic and inclusive (albeit also authoritarian) vision of national identity came to be expressed by way of a governmentpromoted "Pancasila ideology." Despite the crisis of official Pancasila ideology during the early years of the democratic transition, the tradition of an inclusive, civic Indonesian national identity that is blind to ethnic difference has proven resilient, including, it would seem, in the everyday political consciousness of many Indonesian citizens. The notion of a civic identity that transcends ethnicity still has a structuring influence on everyday political discourse and interactions, including at the local level. Many scholars of Indonesia over the last decade have expended their energy in describing and analyzing the new politics of ethnicity, drawn by the novelty of this phenomenon. Arguably, in doing so we have lost sight of the larger story of continuing ethnic harmony and the still powerful influence of inclusive nationalist traditions. A task that therefore lies before scholars of Indonesia is to map out the meso- and microlevel mechanisms by which the grand narratives of Indonesian nationalism continue to influence political behavior at the level of the banal and the everyday.

Finally, and most speculatively, we can point to a deep architecture of politics in Indonesia. Scholars of Indonesian politics have yet to develop a method to characterize the fundamental ordering principles of the new post-Suharto politics. In the past, Clifford Geertz's notion of aliran (stream) politics captured the central features of Indonesian political organization in the 1950s and 1960s (Geertz 1959, 1960). According to Geertz, the main actors in Indonesian politics were the socioreligious "streams" that were embodied in the major political parties and their networks of affiliated mass organizations. In the 1970s and 1980s, during the New Order years, the state took center stage in most analyses, with scholars seeing it as standing above society, depoliticizing, directing, and reordering it. If we were to begin to attempt to characterize the fundamentals of political organization in contemporary Indonesia, our characterization would need to combine an emphasis on fragmentation and on patronage. Rather than being a pillared society in which political life is ordered around a few fundamental sociopolitical currents to which citizens 
owe their primary allegiance (as in the aliran politics model), and rather than being a polity in which a centralizing state is all-powerful, Indonesia has become a society with a proliferation of administrative and political power centers. With few exceptions, patronage is the strongest glue that binds political allegiances, loyalties, and organizations. This combination imparts to Indonesian politics a high degree of pragmatism, flexibility, and even opportunism. Indonesia has become the country of the political deal, not the political dream. Such a context does not provide fertile ground for ethnic politics, at least not for ethnic politics of a highly symbolic and ideologically charged variety.

Edward Aspinall is a senior fellow and head of the Department of Political and Social Change, Australian National University. He is the author of numerous articles and books on Indonesian politics, including Opposing Suharto: Compromise, Resistance and Regime Change in Indonesia (2005), Islam and Nation: Separatist Rebellion in Aceh, Indonesia (2009), and (coedited with Marcus Mietzner) Problems of Democratisation in Indonesia: Elections, Institutions and Society (2010).

\section{Notes}

I am very grateful for the first-rate research assistance provided by Sebastian Dettman, who conducted fieldwork in North Sumatra and East Kalimantan, and Eve Warburton, who searched and summarized secondary literature. All the interview material from North Sumatra and East Kalimantan in this article comes from interviews conducted by Sebastian Dettman. Early versions of the article were presented at the meeting of the Association for Asian Studies in Philadelphia in March 2010 and at the Indonesia Study Group at the Australian National University, and I am grateful to participants, especially Donald Emmerson, for their feedback. Further helpful comments were provided by Ken Ward and by two anonymous reviewers for this journal. This research was funded by the Australian Research Council.

1. Even Islam, the religion of approximately 87 percent of the country's population, can be viewed as a marker of ethnic identity in many local contexts in Indonesia. For example, several of the key communal conflicts that accompanied the democratic transition took place along a fault line separating Muslims from Christians. These conflicts had little to do with whether religious precepts should guide political life; instead, religion acted in them primarily as a boundary marker separating the two sides. Likewise, to the extent that members of particular ethnic groups portray their identity as being strongly inflected by Islam, then phenomena such as moves to officially implement aspects of Islamic law in districts (Bush 2008) can also be viewed as assertions of local identities and examples of ethnic politics. Where religious divisions reinforce ethnic ones, matters like construction of minority houses of worship can also become highly controversial in ethnic terms. On the other hand, Islam is seen by political actors in many local contexts as a force that transcends and unites otherwise competing 
ethnic groups. Political contestation about the place that Islam should occupy in the polity also typically involves secularists; liberal, moderate, and conservative Muslims; and Islamists who come from varied ethnic groups and present their arguments in ideological rather than ethnic terms. All of this suggests that Islamic politics writ large is best viewed, at least in the Indonesian context, as a subject in its own right rather than through the lens of ethnicity.

2. Figures on population in the preceding paragraphs are drawn from Suryadinata, Ananta, and Nurvidya 2003.

3. There were twenty-seven provinces for much of the Suharto period, but this number was reduced by one by the independence of East Timor. Indonesia's second-level administrative regions, below the level of the province, are kabupaten, which are located in rural areas (usually translated as districts), and kota, which are urban (usually translated as municipalities). They are headed by, respectively, bupati (district heads or regents) and walikota (mayors). For the sake of convenience in this article I gloss both kabupaten and kota as districts.

4. This figure excludes deaths in Aceh, which remained high until 2005.

5. Self-conscious evocation of local cultural forms and identity seems to be particularly weak in elections in Java. Thus, as Jennifer Lindsay $(2009,225)$ points out in her study of three pilkada in Yogyakarta, "In general the Yogyakarta pilkada did not employ local identity in developing any new kind of election culture." The one exception was a campaign by a prince in the royal house who used symbols of Javanese culture such as gamelan music, kraton costumes, and the like; this candidate, however, finished far behind the incumbent. See Cribb (2001) on the absence of Javanese ethnonationalism.

6. Apriadi Gunawan, "North Sumatra's First Ever Direct Gubernatorial Election Heats Up," Jakarta Post, March 14, 2008. The article contains other examples of ethnic head counting in making electoral calculations.

7. See for example, "Penyusunan Kurikulum Muatan Lokal Suku Dayak Dimulai 2010," TempoInteraktif, December 14, 2009.

8. My thanks to Jeremy Kingsley for this point.

9. Pancasila, or the five principles, is a set of core principles of Indonesian nationalism first coined by Sukarno but elevated to the status of official ideology under Suharto. It is widely seen as mandating national unity at the expense of religious, ethnic, or other sectoral interests.

10. Field notes, Sebastian Dettman, November 2009.

11. "Malam Temu Ramah Kampsya Sepakat Menangkan Syampurno," April 13, 2008, available at www.inimedanbung.com/node/76 (accessed June 28,2010 ). For a more detailed consideration of ethnic appeals and ethnic voting in the 2010 mayoral election in Medan, the capital of North Sumatra, see Aspinall, Dettman, and Warburton (2011).

12. In general terms, however, it is not advisable to reduce ethnic politics to resources alone. Arguments against such reductionism are found, among other places, in Horowitz (1985) and Varshney (2003). For an argument I made along similar lines, in the specific context of separatist conflicts in Indonesia, see Aspinall (2007).

13. Against this argument we may observe that local and ethnic parties were allowed to compete in Indonesia's first democratic election, in 1955, but achieved 
poor results (except in West Kalimantan, where a Dayak Unity Party won about one-third of the vote). However, the political context of the $1950 \mathrm{~s}$, in the immediate aftermath of Indonesia's independence revolution and in the midst of an overpowering emphasis on national unity, was very different from that of the late 1990s and early 2000s, when a wave of localism was sweeping the country.

14. For an elaboration of some of these points in a comparative perspective, see Aspinall (forthcoming).

\section{References}

Aspinall, Edward. 2005. "Elections and the Normalization of Politics in Indonesia." South East Asia Research 13, 2: 117-156.

- 2007. "The Construction of Grievance: Natural Resources and Identity in a Separatist Conflict." Journal of Conflict Resolution 51, 6: 950-972.

- 2009a. "Combatants to Contractors: The Political Economy of Peace in Aceh.” Indonesia 87 (April): 1-34.

- 2009b. Islam and Nation: Separatist Rebellion in Aceh, Indonesia. Stanford: Stanford University Press.

- 2010. "The Irony of Success." Journal of Democracy 21, 2: 20-34.

. Forthcoming. "How Indonesia Survived: Comparative Perspectives on State Disintegration and Endurance." In Indonesia, Islam, and Democratic Consolidation [working title], ed. Mirjam Künkler and Alfred Stepan. New York: Columbia University Press.

Aspinall, Edward, Sebastian Dettman, and Eve Warburton. 2011. "When Religion Trumps Ethnicity: A Regional Election Case Study from Indonesia." South East Asia Research 19: 27-58.

Avonius, Leena. 2003. "Reforming Adat: Indonesian Indigenous People in the Era of Reformasi." Asia Pacific Journal of Anthropology 4, 1: 123-142.

Bakker, Laurens. 2008. "The Strong Arm of Indigeneity: Dayak Politics and Militias in East Kalimantan.” Paper presented to Workshop on the State and Illegality in Indonesia, Australian National University, September 22-24.

Bertrand, Jacques. 2004. Nationalism and Ethnic Conflict in Indonesia. Cambridge: Cambridge University Press.

- 2008. "Ethnic Conflicts in Indonesia: National Models, Critical Junctures, and the Timing of Violence." Journal of East Asian Studies 8: 425-449.

Brown, David, and Ian Wilson. 2007. "Ethnicized Violence in Indonesia: Where Criminals and Fanatics Meet." Nationalism and Ethnic Politics 13, 3: 367403.

Brubaker, Rogers. 2002. "Ethnicity Without Groups.” European Journal of Sociology 43: 163-189.

Buehler, Michael. 2009. "The Rising Importance of Personal Networks in Indonesian Local Politics: An Analysis of District Government Head Elections in South Sulawesi in 2005." In Deepening Democracy in Indonesia? Direct Elections for Local Leaders (Pilkada), ed. Maribeth Erb and Priyambudi Sulistiyanto, 101-124. Singapore: Institute of Southeast Asian Studies.

Bush, Robin. 2008. "Regional Sharia Regulations in Indonesia: Anomaly or Symptom?" In Expressing Islam: Religious Life and Politics in Indonesia, 
ed. Greg Fealy and Sally White, 174-192. Singapore: Institute of Southeast Asian Studies.

Chandra, Kanchan. 2004. Why Ethnic Parties Succeed: Patronage and Ethnic Head Counts in India. Cambridge: Cambridge University Press.

— 2006. "What Is Ethnic Identity and Does It Matter?" Annual Review of Political Science 9: 397-424.

Choi, Nankyung. 2007. "Local Elections and Democracy in Indonesia: The Riau Archipelago." Journal of Contemporary Asia 37, 3: 326-345.

Clark, Samuel, and Blair Palmer. 2008. Peaceful Pilkada, Dubious Democracy: Aceh's Post-Conflict Elections and Their Implications. Indonesian Social Development Paper No. 11. Jakarta: World Bank.

Collier, Paul. 2010. Wars, Guns and Votes: Democracy in Dangerous Places. London: Vintage.

Cribb, Robert. 1999. "Not the Next Yugoslavia: Prospects for the Disintegration of Indonesia." Australian Journal of International Affairs 53, 2: 169-178.

2001. "Independence for Java? New National Projects for an Old Empire." In Indonesia Today: Challenges of History, ed. Grayson Lloyd and Shannon L. Smith, 298-307. Singapore: Institute of Southeast Asian Studies.

Davidson, Jamie S. 2008. From Rebellion to Riots: Collective Violence on Indonesian Borneo. Madison: University of Wisconsin Press.

DeVotta, Neil. 2005. "From Ethnic Outbidding to Ethnic Conflict: The Institutional Bases for Sri Lanka's Separatist War." Nations and Nationalism 11, 1: 141-159.

Dick, Howard, and Jeremy Mulholland. 2011. "The State as Marketplace: Slush Funds and Intra-elite Rivalry." In The State and Illegality in Indonesia, ed. Edward Aspinall and Gerry van Klinken, 65-85. Leiden: KITLV Press.

Diprose, Rachael. 2002. Putra Daerah: Identity, Grievances, and Collective Action in Indonesia. Honours thesis, University of New South Wales.

- 2006. "Passing on the Challenges or Prescribing Better Management of Diversity? Decentralization, Power Sharing and Conflict Dynamics in Central Sulawesi, Indonesia." Paper presented at the CRISE/University of Oxford Conference on Federalism, Decentralization and Conflict, October 5-7.

Drexler, Elizabeth F. 2008. Aceh, Indonesia: Securing the Insecure State. Philadelphia: University of Pennsylvania Press.

Duncan, Christopher R. 2009. "Reconciliation and Revitalization: The Resurgence of Tradition in Postconflict Tobelo, North Maluku, Eastern Indonesia." Journal of Asian Studies 68, 4: 1077-1104.

Erb, Maribeth, and Wilhelmus Anggal. 2009. "Conflict and the Growth of Democracy in Manggarai District." In Deepening Democracy in Indonesia? Direct Elections for Local Leaders (Pilkada), ed. Maribeth Erb and Priyambudi Sulistiyanto, 283-302. Singapore: Institute of Southeast Asian Studies.

Erb, Maribeth, and Priyambudi Sulistiyanto (eds.). 2009. Deepening Democracy in Indonesia? Direct Elections for Local Leaders (Pilkada). Singapore: Institute of Southeast Asian Studies.

Esman, Milton J. 1994. Ethnic Politics. Chicago: University of Chicago Press. 
Faucher, Carole. 2006. "Popular Discourse on Identity Politics and Decentralisation in Tanjung Pinang Public Schools." Asia Pacific Viewpoint 47, 2: 273-285.

- 2007. "Contesting Boundaries in the Riau Archipelago." In Renegotiating Boundaries: Local Politics in Post-Suharto Indonesia, ed. Henke Schulte Nordholt and Gerry Van Klinken, 443-458. Leiden: KITLV Press.

Fauzan, Achmad Uzair. 2009. "Winning the Villages." Inside Indonesia 97 (JulySeptember).

Fenton, Steve. 1999. Ethnicity: Racism, Class and Culture. Lanham, MD: Rowman \& Littlefield.

Geertz, Clifford. 1959. "The Javanese Village.” In Local, Ethnic and National Loyalties in Village Indonesia, ed. G. William Skinner, 34-41. New Haven: Yale University Cultural Report Series.

- 1960. The Religion of Java. Glencoe, IL: Free Press of Glencoe.

Hadiz, Vedi R. 2003. "Power and Politics in North Sumatra: The Uncompleted Reformasi." In Local Power and Politics in Indonesia: Decentralisation and Democratisation, ed. Edward Aspinall and Greg Fealy, 119-131. Singapore: Institute of Southeast Asian Studies.

Henley, David, and Jamie S. Davidson. 2007. "Introduction: Radical Conservatism-the Protean Politics of Adat." In The Revival of Tradition in Indonesian Politics: The Deployment of Adat from Colonialism to Indigenism, ed. Jamie S. Davidson and David Henley, 1-49. New York: Routledge.

Henley, David, Maria J. C. Schouten, and Alex J. Ulaen. 2007. "Preserving the Peace in Post-New Order Minahasa." In Renegotiating Boundaries: Local Politics in Post-Suharto Indonesia, ed. Henke Schulte Nordholt and Gerry van Klinken, 307-326. Leiden: KITLV Press.

Horowitz, Donald L. 1985. Ethnic Groups in Conflict. Berkeley: University of California Press.

ICG (International Crisis Group). 2005. Decentralisation and Conflict in Indonesia: The Mamasa Case. Asia Briefing No. 37. Jakarta/Brussels: ICG.

- 2009. Local Election Disputes in Indonesia: The Case of North Maluku. Asia Briefing No. 86. Jakarta/Brussels: ICG.

Jacobsen, Michael. 2000. "Indonesia on the Threshold. Towards an Ethnification of the Nation?" IIAS News Letter 22: 22.

Kimura, Ehito. 2010. "Proliferating Provinces: Territorial Politics in PostSuharto Indonesia.” South East Asia Research 18, 3 (September): 415-449.

Kristiansen, Stein, and Muhid Ramli. 2006. "Buying an Income: The Market for Civil Service Positions in Indonesia." Contemporary Southeast Asia 28, 2: 207-233.

Li, Tania. 2007. "Adat in Central Sulawesi: Contemporary Deployments." In The Revival of Tradition in Indonesian Politics: The Deployment of Adat from Colonialism to Indigenism, ed. Jamie S. Davidson and David Henley, 337-370. New York: Routledge.

Liddle, R. William, and Saiful Mujani. 2007. "Leadership, Party, and Religion: Explaining Voting Behavior in Indonesia." Comparative Political Studies 40, 7: 832-857. 


\section{$35-49$.}

Lindsay, Jennifer. 2009. "Pomp, Piety and Performance: Pilkada in Yogyakarta, 2005." In Deepening Democracy in Indonesia? Direct Elections for Local Leaders (Pilkada), ed. Maribeth Erb and Priyambudi Sulistiyanto, 211-228. Singapore: Institute of Southeast Asian Studies.

Lingkaran Survei Indonesia. 2008. "Faktor Etnis dalam Pilkada." Laporan Bulanan 9: 1-22.

McRae, Dave. 2010. "Reintegration and Localised Conflict: Security Impacts Beyond Influencing Spoilers." Conflict, Security and Development 10: 403-430.

Mietzner, Marcus. 2006. "Local Democracy." Inside Indonesia 85: 17-18.

- 2007. "Local Elections and Autonomy in Papua and Aceh: Mitigating or Fueling Secessionism?" Indonesia 84: 1-39.

- 2009. "Autonomy, Democracy, and Internal Conflict: The 2006 Gubernatorial Elections in Papua." In Deepening Democracy in Indonesia? Direct Elections for Local Leaders (Pilkada), ed. Maribeth Erb and Priyambudi Sulistiyanto, 259-282. Singapore: Institute of Southeast Asian Studies.

Palmer, Blaair. 2010. "Peace, Patronage and Post-Conflict Elections in Aceh." In Problems of Democratisation in Indonesia: Elections, Institutions and Society, ed. Edward Aspinall and Marcus Mietzner, 286-306. Singapore: Institute of Southeast Asian Studies.

Rasyid, M. Ryaas. 2003. "Regional Autonomy and Local Politics in Indonesia." In Local Power and Politics in Indonesia: Democratisation and Decentralisation, ed. Edward Aspinall and Greg Fealy, 63-71. Singapore: Institute of Southeast Asian Studies.

Schiller, Anne. 2007. "Activism and Identities in an East Kalimantan Dayak Organization." Journal of Asian Studies 66, 1: 63-95.

Schulte Nordholt, Henk. 2007. Bali, an Open Fortress 1995-2005: Regional Autonomy, Electoral Democracy and Entrenched Identities. Singapore: National University of Singapore Press.

- 2008. "Identity Politics, Citizenship and the Soft State in Indonesia: An Essay." Journal of Indonesian Social Sciences and Humanities 1: 1-21.

Schulte Nordholt, Henk, and Gerry van Klinken, eds. 2007. Renegotiating Boundaries: Local Politics in Post-Suharto Indonesia. Leiden: KITLV Press.

Smith, Anthony D. 1986. The Ethnic Origins of Nations. Oxford: Blackwell.

Smith, Claire Q. 2009. "The Return of the Sultan? Patronage, Power, and Political Machines in 'Post'-Conflict North Maluku." In Deepening Democracy in Indonesia? Direct Elections for Local Leaders (Pilkada), ed. Maribeth Erb and Priyambudi Sulistiyanto, 303-326. Singapore: Institute of Southeast Asian Studies.

Subianto, Benny. 2009. "Ethnic Politics and the Rise of the Dayak Bureaucrats in Local Elections: Pilkada in Six Kabupaten in West Kalimantan." In Deepening Democracy in Indonesia? Direct Elections for Local Leaders (Pilkada), ed. Maribeth Erb and Priyambudi Sulistiyanto, 327-351. Singapore: Institute of Southeast Asian Studies. 
Suryadinata, Leo, Aris Ananta, and Evi Nurvidya. 2003. Indonesia's Population: Ethnicity and Religion in a Changing Political Landscape. Singapore : Institute of Southeast Asian Studies.

Tajima, Yuhki. 2004. Mobilizing for Violence: The Escalation and Limitation of Identity Conflicts. The Case of Lampung, Indonesia. Indonesian Social Development Paper No. 3. Jakarta: World Bank.

Tomsa, Dirk. 2009. "Electoral Democracy in a Divided Society: The Gubernatorial Election in Maluku." South East Asia Research 17, 2: 229-259.

van Klinken, Gerry. 2007. Communal Violence and Democratization in Indonesia: Small Town Wars. London: Routledge.

- 2008. "The Limits of Ethnic Clientelism in Indonesia." Review of Indonesian and Malaysian Affairs 42, 2: 35-65.

Varshney, Ashutosh. 2003. "Ethnic Conflict, Nationalism and Rationality." Perspectives on Politics 1, 1: 85-99.

Varshney, Ashutosh, Rizal Panggabean, and Mohammad Zulfan Tadjoeddin. 2004. Patterns of Collective Violence in Indonesia (1990-2003). Jakarta: United Nations Support Facility for Indonesian Recovery.

Vel, Jacqueline. 2005. "Pilkada in East Sumba: An Old Rivalry in a New Democratic Setting." Indonesia 80: 81-107.

Wilson, Chris. 2008. Ethno-Religious Violence in Indonesia: From Soil to God. London: Routledge.

Wilson, Ian. 2010. "The Rise and Fall of Political Gangsters in Indonesian Democracy." In Problems of Democratisation in Indonesia: Elections, Institutions and Society, ed. Edward Aspinall and Marcus Mietzner, 199-218. Singapore: Institute of Southeast Asian Studies. 


\section{A N N O U N C E M E N T FELLOWS PROGRAM \\ on}

Peace, Governance, and Development in East Asia

\section{The East Asia Institute (EAI) in Seoul, South Korea,} EAI Fellowship that has been established since 2005. To encourage interdisciplinary research with a comparative perspective in East Asian studies, fellows will:

- Study with East Asia specialists with cutting-edge expertise in political science, international relations, and sociology

- Visit partner institutions (EAl, Keio University, National Taiwan University, Peking University, and Fudan University) to present their research at seminars and lectures

- Receive grants of $\$ 8,000$ to $\$ 10,000$ per fellow

Five fellows will be accepted for the 2011-2012 program Applications must be received no later than September 2, 2011

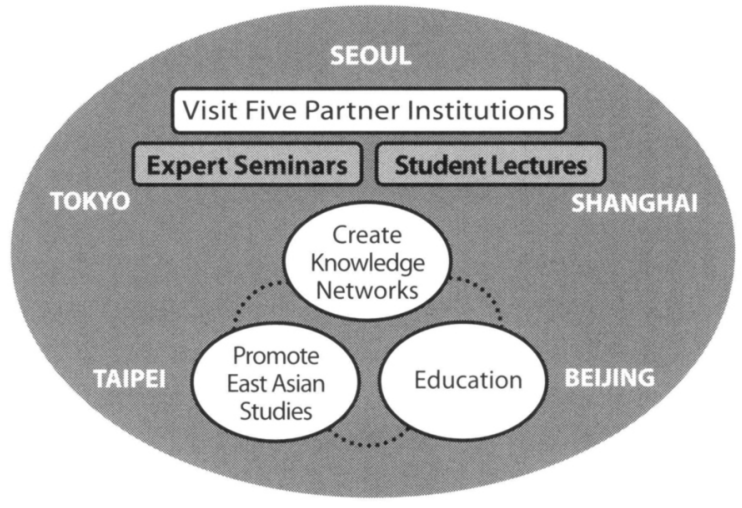

Funded by the Japan Foundation, the Chiang Ching-kuo Foundation for International Exchange in Taiwan, and YBM/KIS, an educational institute in South Korea.

For more information contact:

fellowships@eai.or.kr

www.eai.or.kr

P. 82-2-2277-1683 F. $82-2-2277-1684$

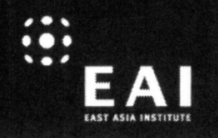

The East Asia Institute, \#909 Sampoong Building, 310-68 Euljiro 4-ga, Jung-gu, Seoul 100-786, Korea 